Volume 19 Number 1 June 2019.

https://doi.org/10.30603/au.v19i1.693

\title{
Faham Tentang Larangan Shalat Jumat Bagi Wanita di Gorontalo
}

\author{
Dulsukmi Kasim
}

IAIN Sultan Amai Gorontalo

\begin{abstract}
Abstrak
Tulisan ini mengangkat kasus faham shalat Jumat muslimah Desa Bulotalangi Timur yang ada di Kecamatan Bulango Timur Kabupaten Bone Bolango. Dari tiga masjid yang ada di desa Bulotalangi Timur, hanya masjid al-Hidayah yang muslimahnya menjalankan faham bahwa wanita tidak boleh shalat Jumat, sehingga mereka datang ke masjid pada hari Jumat hanya untuk shalat Dhuhur berjamaah dan diimami seorang pria. Faham ini muncul sejak tahun 1994 yang diajarkan oleh seorang guru ngaji bernama Karim Daud. Tidak dijumpai adanya dalil nas khusus dalam menjalankan faham tersebut. Langgengnya faham tersebut dipicu oleh sedikitnya 4 faktor: 1) Rendahnya tingkat pendidikan dan pengetahuan agama warga desa tersebut; 2) Kurangnya perhatian dari lembaga pemerintah dan tokoh masyarakat setempat; 3) Adanya fanatisme buta atas doktrin sang guru/ustad; 4) Kurang tersentuhnya mereka oleh dakwah ulama Gorontalo (MUI, Kementerian Agama, dan da ’i).
\end{abstract}

Kata Kunci: Kewajiban Hak Asasi Manusia (HAM), Hukum Pidana Islam

Author correspondence

Email: dulsukmikasimiaingorontalo.ac.id

Available online at http://journal.iaingorontalo.ac.id/index.php/au/index 


\section{Dulsukmi Kasim}

\section{A. Pendahuluan}

Shalat jumat merupakan ibadah mahdah yang disyariatkan bagi umat Islam. Selain berfungsi sebagai ibadah ritual, shalat jumat juga merupakan reuni akbar kaum muslimin setiap pekan. Sebagaimana tercantum dalam QS. Al-Jumu'ah/62: 9.

Dalam ranah fiqh, shalat Jumat telah disepakati berada pada level hukum fardhu ' ain $^{l}$ bagi kaum laki-laki yang mukallaf. ${ }^{2}$ Sementara hamba sahaya, kaum wanita, anak kecil, orang sakit, dan para musafir diberi rukhshah untuk meninggalkannya. ${ }^{3}$ Sebagaiman informasi dari Hadis Nabi saw. dari Thariq bin Syihab riwayat Abu Daud. ${ }^{4}$

Hadis tersebut sekaligus menegaskan disyaratkannya berjamaah dalam menjalankan shalat Jumat. Itu berarti ada tujuan besar yang ingin diwujudkan Tuhan dibalik syariat tersebut yakni silaturrahim. Itulah sebabnya, Nabi saw menyebutnya sebagai hari raya dan diharamkan berpuasa di dalamnya. Kecuali jika berpuasa juga sebelumnya (kamis) atau sesudahnya (sabtu). Sebagaimana sabda Nabi saw dari Amir al-Asy’ari dari Abi Hurairah riwayat Ibnu Khuzaimah. ${ }^{5}$

Dilihat dari posisi hukum dan tujuan agung tersebut, sejatinya pelaksanaan syariat shalat Jumat tidak lagi menuai problem dalam teknis pelaksanaannya di masyarakat. Sebab, yang namanya syariat itu bersifat ilahi atau statis, menganut prinsip universal dan tidak berubah-ubah. ${ }^{6}$ Tidak boleh ada perubahan dan keragaman dalam teknis pelaksanaannya. Tapi ternyata masih ada saja beberapa persoalan seputar shalat Jumat yang masih sering dijumpai di masyarakat. Antara lain, masih adanya orang yang melaksanakan shalat Dhuhur setelah selesai shalat Jumat. Disyaratkannya

\footnotetext{
${ }^{1}$ Fardu 'ain adalah sesuatu yang dituntut oleh syari' (pembuat hukum) untuk dilaksanakan oleh setiap pribadi mukallaf dan tidak boleh diwakilkan kepada orang lain. Lihat, Amir Syarifuddin, Ushul Fiqh 1, Cet. III; Jakarta: Kencana, 2008, h. 324.

${ }^{2}$ Mukallaf adalah orang yang dipandang oleh agama cakap dan layak dibebani atau menjalankan suatu tuntutan perbuatan hukum. Yaitu orang yang terpenuhi pada dirinya minimal dua hal, yakni pengetahuan akan adanya tuntutan Allah (berakal) dan kemampuan melaksanakan tuntutan Allah tersebut (balig). Amir Syarifuddin, Ushul Fiqh 1, h. 389.

3 Syaikh Kamil bin Uwaidah, al-Jami' fi Fiqh al-Nisa', diterjemahkan oleh M. Abdul Ghoffar E.M dengan judul “Fiqh Wanita (Edisi Lengkap), Cet. X; Jakarta: Pustaka al-Kautsar, 2002, h. 156-157.

${ }^{4}$ Muhammad bin Ismail al-Yamany al-Shan'any, Subul al-Salām, Juz 2, Mansoura: Makatabat al-Iman, t.t., h. 99.

${ }^{5}$ Muhammad bin Ishak bin Khuzaimah al-Naisabury, Shahih Ibnu Khuzaimah, Juz 3, Cet. II; Beirut: alMaktab al-Islamy, 1992, h. 318. Walaupun al-A'dhzamiy mengatakan sanad hadis ini lemah, namun alHakim dalam kitab "al-Mustadrak" menyebutkan bahwa hadis ini sanadnya sahih. Lihat, Imam alHakim an-Naisabury, al-Mustadrak, Juz 1, h. 603.

${ }^{6}$ Dedi Sumardi "Islam, Pluralisme Hukum dan REfleksi Masyarakat Homogen" Asy-Syir'ah; Vol. 50, No. 2, Desember 2016, UIN Ar-Raniry Banda Aceh, h. 488.
} 
jumlah jamaah tertentu dalam untuk shalat jumat. Tidak bolehnya wanita shalat jumat. ${ }^{7}$ Ada lagi kasus tentang shalat Jumat dua gelombang bagi pegawai pabrik atau pekerja industri. ${ }^{8}$ Termasuk ta'addud al-Jum'at (banyaknya pelaksanaan shalat jumat) dalam satu desa atau kampung atau terjadinya gantian shift untuk shalat Jumat. ${ }^{9}$ Berbagai kasus tersebut menunjukkan bahwa persoalan shalat Jumat masih aktual untuk diangkat dan diteliti.

Salah satu kasus seputar shalat Jumat yang ditemukan di Gorontalo adalah adanya masyarakat di desa Bulotalangi Timur yang melarang kaum wanitanya untuk melaksanakan shalat Jumat. Meski mereka datang memenuhi panggilan azan Jumat, namun sesampai di masjid mereka hanya mendengar khutbah dan tidak melakukan shalat jumat bersama kaum pria sebagaimana lazimnya. Setelah jemaah laki-laki selesai shalat Jumat, salah seorang pria yang telah menjalankan shalat jumat menuju ke shaf wanita untuk mengimami jemaah wanita yang belum shalat jumat tadi. Bukan untuk shalat jumat tetapi untuk melaksanakan shalat Dhuhur berjamaah. Apabila tidak ada pria yang bersedia mengimami, maka para wanita tersebut kembali ke rumah masing-masing tanpa melaksanakan shalat Dhuhur.

Kasus wanita menghadiri shalat Jumat di masjid sejatinya telah jelas dari sisi hukum sebab para ulama telah membahasnya dalam berbagai karya mereka. Antara lain, kitab "al-Fiqh al-Wadhih min al-Kitab wa al-Sunnah 'ala al-madzahib al-arba'ah" karya Muhammad Bakr Ismail menyebutkan "dan tidak diwajibkan bagi wanita (shalat Jumat). Namun, andai ia datang menjalankannya bersama jamaah (laki-laki) maka ibadah shalat Jumatnya sah dan itu telah menutupi kewajibannya menjalankan shalat Dhuhur". 10

Sejalan dengan itu, Syaikh Kamil Muhammad Uwaidah dalam buku "Fiqh Wanita" menyebutkan:

"Shalat Jumat ini tidak diwajibkan bagi wanita muslimah dan anak-anak. Hal ini telah menjadi kesepakatan para ulama dan kaum muslimin secara

\footnotetext{
${ }^{7}$ Ahmad Bisyri Syakur, Fiqh Tradisi; Cara Baru Memandang Tradisi Islam di Indonesia, Cet. I; Bandung: Salamadani, 2013, h. 119.

${ }^{8}$ Himpunan Fatwa Majelis Ulama Indonesia Sejak 1975, Jakarta: Erlangga, 2011, h. 176.

${ }^{9}$ Ahmad Yani Nasution “Ta'addud al-Jum'at Menurut Empat Mazhab”, Jurnal Mandiri, Vol. I, No.1, Juni 2017, Lembaga Kajian Demokrasi dan Pemberdayaan Masyarakat, h. 24.

${ }^{10}$ Muhammad Bakr Ismail, al-Fiqh al-Wadhih min al-Kitab wa al-Sunnah 'ala al-madzahib al-arba'ah, Jilid 1, Cet. II; Kairo: Dar al-Manar, 1997, h. 226.
} 
keseluruhan .......akan tetapi mereka (wanita) tetap berkewajiban untuk mengerjakan shalat dzuhur kecuali anak kecil yang belum balig. Bagi siapa di antara mereka (wanita) yang mengerjakan shalat Jumat, maka shalatnya sah dan kewajiban mengerjakan shalat dzuhurnya pun menjadi gugur". ${ }^{11}$

Selanjutnya Syaikh Kamil menyatakan bahwa pada zaman Rasulullah saw kaum wanita muslimah pun tetap datang ke masjid dan ikut mengerjakan shalat jumat bersama beliau dan mereka tidak lagi mengerjakan shalat Dhuhur sesudahnya. ${ }^{12}$

Lebih tegas lagi adalah pandangan dari Sayyid Sabiq dalam buku "Fiqh alSunnah" bahwa "Adapun pelaksanaan shalat dzuhur bagi yang telah melaksanakan shalat Jumat, maka disepakati hal itu tidak boleh karena shalat Jumat adalah pengganti shalat dzuhur dan menggantikan posisinya. Sesungguhnya Allah tidak pernah mewajibkan bagi kita enam waktu shalat dalam sehari. Maka barang siapa yang membolehkan shalat dzuhur setelah shalat Jumat, maka hal itu tidak punya landasan, baik secara logika, keterangan (penuqilan dari Sahabat Nabi), Nas (al-Qur'an dan Sunnah), serta perkataan salah seorang imam madzhab pun". ${ }^{13}$

Dalam buku “Rahasia dan Keutamaan Hari Jumat”, Komarudin Ibnu Mikam menyatakan bahwa melakukan shalat dzuhur sesudah shalat jumat menurut jumhur ulama hukumnya tidak boleh. Sebab jumat adalah pengganti shalat dzuhur. Allah juga tidak mewajibkan shalat enam waktu sehari semalam. Namun jika dalam pelaksanaan shalat jumat terdapat kekurangan dalam rukunnya dibolehkan melaksanakan shalat Dhuhur. ${ }^{14}$

Berdasarkan keterangan ulama dan informasi dari berbagai literatur tersebut menunjukkan bahwa persoalan shalat Jumat bagi wanita sebenarnya telah final dan jelas kedudukan hukumnya. Cuma memang, bila diamati lebih dalam sepertinya kasus yang ditemukan di kalangan masyarakat muslimah desa Bulotalangi Timur agak unik dan cenderung berbeda dari apa yang sering dijumpai dan dibahas oleh para ulama. Oleh karena itu, masalah pokoknya adalah mengapa wanita di desa tersebut dilarang untuk melaksanankan shalat Jumat? Mengapa mereka tidak melaksanakan shalat Jumat

\footnotetext{
${ }^{11}$ Syaikh Kamil bin Uwaidah, al-Jami' fi Fiqh al-Nisa', h. 156-157.

${ }^{12}$ Syaikh Kamil bin Uwaidah, al-Jami' fi Fiqh al-Nisa', h. 156-157.

${ }^{13}$ al-Sayyid Sabiq, Fiqh al-Sunnah, Juz: 1, Cet. II; Cairo: Dar al-Fath li al-I'lam al-‘Araby, 1999, h. 360.

${ }^{14}$ Komarudin Ibnu Mikam, Rahasia dan Keutamaan Hari Jumat, Cet. I; Jakarta: QultumMedia, 2007, h. 70 .
} 
secara bersama dengan jamaah laki-laki dan hanya menjalankan shalat Dhuhur? Apa landasan berfikir mereka dalam menjalankan faham shalat Jumat seperti itu hingga tetap bersikukuh mempertahankan faham tersebut? Faktor apa saja yang memicu langgengnya faham tersebut diberpegangi oleh penganutnya?

\section{B. Sejarah Pensyariatan Shalat Jumat}

Kata Jumat memiliki tiga bentuk mufrad, yaitu: Jum'ah, Juma'ah, dan Jumu'ah. Ketiganya menunjuk pada hari sesudah hari kamis yang merupakan hari terakhir dalam sepekan yang esok harinya disebut hari sabtu. Yaitu hari berkumpulnya umat Islam di masjid untuk melaksanakan ibadah shalat Jumat. ${ }^{15}$ Pada masa pra Islam orang Arab Jahiliyah menamakan hari Jumat dengan hari 'arūbah. ${ }^{16}$ Adapun orang yang pertama kali menamakannya dengan hari jumat adalah Ka'ab bin Lu'ay di mana ia mengumpulkan kaumnya pada hari itu sambil memberi mereka taushiyah/nasehat dan menyuruhnya untuk mengagungkan Baitullah al-Haram. ${ }^{17}$ Pendapat lain mengatakan bahwa alasan dinamakannya dengan Jumat adalah karena sempurnanya penciptaan seluruh makhluk terjadi pada hari itu. ${ }^{18}$ Namun mayoritas ulama sepakat mengatakan bahwa sebab atau alasan dinamakannya dengan Jumat adalah karena manusia berkumpul pada hari itu untuk shalat di masjid yang kemudian dikenal dengan nama ibadah shalat Jumat sebagai ganti dari shalat Zuhur. ${ }^{19}$

Beralih ke persoalan historis hadirnya pensyariatan ibadah Jumat di hari itu. Dari berbagai kitab Tafsir ditemukan informasi bahwasanya ibadah shalat Jumat pertama kali telah disyariatkan di Mekah, namun belum dapat dilaksanakan karena dua pertimbangan. Pertama, karena jumlah kaum muslimin yang masih sedikit. Kedua, karena shalat Jumat syiarnya harus dinampakkan, sementara saat itu Nabi Muhammad dan kaum muslimin masih cenderung menyembunyikan aktifitas ibadahnya. ${ }^{20}$

\footnotetext{
${ }^{15}$ Ahmad Mukhtar Abdul Hamid Umar, Mu'jam al-Lugah al-Arabiyyah al-Mu'āṣirah, Juz 1, Cet. I; Cairo: 'Ālam al-Kitāb, 2008, h. 396.

${ }^{16}$ Menurut al-Suhaili, al-'Aruubah berarti rahmat. Lihat pula, Al-Alūsì al-Bagdādì, Rūh al-Ma'ānī fi Tafsiri al-Qur'āni al-Ażìm wa al-Sab'i al-Matsānī, Juz 28, Beirut: Dār Ihyā' al-Turāts al-'Arabì, t.th, h. 99.

${ }^{17}$ Wahbah al-Zuhaily, al-Tafsir al-Munir, Juz 28, Cet. II; Damaskus: Dar al-Fikr al-Mu'ashir, 1418 H., h. 195.

${ }^{18}$ Komarudin Ibnu Mikam, Rahasia dan Keutamaan Hari Jumat, h. 2.

${ }^{19}$ Wahbah al-Zuhaily, al-Fiqh al-Isalamy wa Adillatuh, Juz 2, Cet. IV; Damaskus: Dar al-Fikr, 2002, h. 1278.

${ }^{20}$ Wahbah al-Zuhaily, al-Tafsir al-Munir, Juz 28, h. 195.
} 
Menurut Wahbah al-Zuhaily, orang yang pertama kali mengumpulkan manusia untuk menjalankan shalat Jumat sebelum hijrahnya Nabi Muhammad ke Madinah adalah As'ad bin Zurrārah bersama Mush'ab bin Umaïr di sebuah desa yang berjarak 1 mil dari kota Madinah. Adapun Nabi Muhammad saw. baru sempat menjalankan shalat jumat untuk pertama kalinya di tempat balai pertemuan (dār) Bani Sālim di daerah Qubā' saat melakukan hijrah. ${ }^{21}$

\section{Landasan Hukum Pelaksanaan Shalat Jumat}

Telah menjadi kesepakatan di antara ulama bahwa hukum asal menjalankan shalat Jumat bagi mukallaf adalah Fardhu 'Ain. ${ }^{22}$ Hukum tersebut didasarkan pada perintah Allah pada surah al-Jumu'ah ayat 9. Menurut al-Qurthubi, dalam ayat tersebut Allah menyeru kepada orang yang beriman secara khusus. Itu tidak lain bermakna sebagai penghormatan dan pemuliaan kepada mereka yang beriman pada ajaran Islam. Sekaligus menunjukkan wajibnya menjalankan shalat Jumat dan penegas akan pensyariatannya bagi umat Islam. Kalimat " $Y \bar{a}$ Ayyuhallażina Amanü pada pembukaan ayat tersebut juga merupakan panggilan bagi para mukallaf. Jadi, orang sakit, musafir, hamba sahaya dan wanita tidak termasuk dalam panggilan tersebut. Sebagaimana ditegaskan oleh hadis Nabi dari Thariq bin Syihab. ${ }^{23}$

Dalam hadis Nabi juga ditemukan dalil diwajibkannya shalat Jumat bagi para mukallaf, di antaranya hadis dari Ibnu Mas'ud yang diriwayatkan oleh Muslim dan Ahmad bahwa Nabi saw bersabda kepada kaum yang tidak menjalankan shalat Jumat "sungguh aku pernah berfikir untuk memerintahkan kepada seseorang untuk memimpin shalat Jumat di masjid kemudian aku pergi membakar rumah orang-orang yang tidak shalat Jumat pada hari itu". ${ }^{24}$

Berdasarkan hadis di atas, melaksanakan shalat Jumat bagi mukallaf hukumnya menunjukkan wajib. Hal itu difahami setelah adanya ancaman dari Rasulullah saw. yang hendak beliau lakukan bagi orang-orang yang berani meninggalkannya tanpa alasan yang diperkenankan oleh syara'. Dengan demikian, shalat Jumat merupakan

\footnotetext{
${ }^{21}$ Lihat, Wahbah al-Zuhaily, al-Fiqh al-Islamy wa Adillatuh, h. 1278.

${ }^{22}$ Lihat, al-Sayyid Sabiq, Fiqh al-Sunnah, Jilid. 1, h. 327.

${ }^{23}$ Al-Qurthuby, Jami' li Ahkam al-Qur'an, Jilid 9, Juz 18, Cet. I; Beirut: Dar al-Kutub al-Ilmiyyah, 2000, h. 65-68.

${ }^{24}$ Muslim bin al-Hajjaj Abul Hasan al-Qusyairy al-Naisabury, Sahih Muslim, Juz 1, Bab: Fadhlu Shalat al-Jumu'ah, Beirut: Dar Ihya al-Turats al-Araby, h. 452.
} 
kewajiban bagi mukallaf yang hukumnya diperoleh melalui petunjuk al-Qur'an, Sunnah, dan Ijmak sehingga sudah sampai pada tingkat aksioma.

\section{Rukun dan Syarat Sah Ibadah Jumat}

Wahbah al-Zuhaily menyatakan bahwa Jumat memiliki dua rukun, yaitu: Khutbah dua kali dan shalat jumat dua rakaat. Adapun syarat sah Jumat merupakan syarat-syarat sah shalat pada umumnya, lalu ditambah beberapa persyaratan khusus lainnya yang jumlahnya terdapat perbedaan di antara ulama madzhab. Menurut Hanafiyyah dan Syafiiyyah ada 7 syarat, menurut Malikiyyah 5 syarat, dan menurut Hanabilah 4 syarat. $^{25}$

Semua syarat-syarat yang disebutkan oleh ulama fikih dari berbagai mazhab tersebut dapat dirangkum ke dalam enam syarat utama, yaitu:

1. Dilaksanakan di waktu Dhuhur

2. Dilaksanakan dalam suatu negeri/kampung

3. Dilaksanakan secara berjamaah

4. Dilaksanakan di masjid jami'

5. Ada yang bertindak sebagai imam dan khatib

6. Khutbah dilakukan sebelum pelaksanaan shalat jumat

Bila dua rukun Jumat tersebut plus enam syarat khususnya di atas telah terpenuhi, ditambah terpenuhinya syarat sah shalat berjamaah secara umum, kemudian pelaksanaannya terhindar dari hal-hal yang membatalkan dan yang memakruhkannya, maka sesuai kaidah ushul fiqh ibadah Jumat yang dijalankan sudah disebut sah.

\section{E. Orang Yang Wajib dan Yang Tidak Wajib Shalat Jumat}

Sayyid Sabiq, menyebutkan bahwa orang yang dituntut dan wajib baginya menjalankan shalat Jumat adalah Muslim, Balig, Berakal, Laki-laki, Merdeka, dan Tidak ada użur (halangan). Sementara Wahbah al-Zuhaily menambahkan satu syarat, yaitu Muqim/Tidak melakukan perjalanan. ${ }^{26} \mathrm{Hal}$ ini didasarkan pada hadis Thariq bin Syihab yang mengecualikan empat golongan yang tidak wajib untuk menjalankan

\footnotetext{
${ }^{25}$ Wahbah al-Zuhaily, al-Fiqh al-Islamy wa Adillatuh, h. 1291-1292.

${ }^{26}$ al-Sayyid Sabiq, Fiqh al-Sunnah, h. 268. Lihat pula, Wahbah al-Zuhaily, al-Fiqh al-Islamy wa Adillatuh, h. 1285-1290.
} 
shalat Jumat, maka logika terbaliknya adalah selain yang empat golongan itu adalah wajib menjalankan shalat Jumat, yaitu: Laki-laki, orang merdeka, anak yang sudah balig/berakal, dan orang sehat, serta muqim.

Lebih jelasnya, Sayyid Sabiq menyebutkan 6 golongan yang dikategorikan sebagai orang yang ma’żür sehingga tidak wajib shalat Jumat, yaitu: 1) Wanita; 2) Anak kecil; 3) Orang sakit yang sakitnya akan tambah parah atau lambat sembuhnya bila pergi shalat Jumat. Termasuk orang buta yang tidak mendapat orang yang bisa menuntunnya ke masjid, kecuali bila ia mampu sampai di masjid seorang diri tanpa kesulitan. Selain itu, orang yang sudah sangat tua dan pikun yang sulit menghadirinya. ${ }^{27}$; 4) Musafir; 5) Orang yang ketakutan ditangkap oleh penguasa yang zalim, atau orang yang takut kehilangan harta, jiwa, atau kehormatannya karena situasi negeri yang tidak aman. ${ }^{28}$; 6) Orang yang berhalangan karena kondisi alam/cuaca. Yaitu termasuk di dalamnya semua użur yang diberi keringanan oleh syara' untuk meninggalkan shalat Jama'ah, seperti karena turun hujan lebat, banjir (air, lumpur), longsor, udara sangat dingin atau sangat panas. ${ }^{29}$

Semua użur di atas bila dialami seorang muslim maka tidak wajib baginya mengerjakan shalat Jumat di masjid, cukup dia shalat shalat Dhuhur saja di rumah. Seandainya mereka tetap datang melakukan shalat Jumat, maka shalat Jumatnya tetap sah dan gugurlah kewajiban menjalankan shalat Dhuhur.

\section{F. Hukum Wanita Melaksanakan Shalat Jumat}

Sesuai pemaparan di atas, kaum wanita tidak diwajibkan oleh agama untuk datang menjalankan shalat Jumat di masjid di hari Jumat. Namun demikian, bila seorang wanita tetap datang ke masjid tanpa ada penghalang ('użur syar'i) untuk shalat, lalu ia menunaikan shalat Jumat bersama kaum lelaki, maka shalat jumatnya sah dan mereka tidak perlu lagi shalat Dhuhur sesudah itu.

Sebagai dalil atas asumsi di atas, Ahmad al-Syurbashi menyebutkan bahwa pada masa Nabi saw di Madinah beberapa orang wanita menghadiri shalat Jumat

\footnotetext{
${ }^{27}$ Ahmad al-Syurbashi, Yas'alunaka fi al-Din wa al-Hayah, diterjemahkan oleh Ahmad Subandi denan judul "Yas'alunaka; Tanya Jawab Tentang Agama dan Kehidupan", Buku V, Cet. VI; Jakarta: Lentera, 2007, h. 34.

${ }^{28}$ Ahmad al-Syurbashi, Yas'alunaka fi al-Din wa al-Hayah, h. 34.

${ }^{29}$ al-Sayyid Sabiq, Fiqih Shalat, h. 269.
} 
bersamanya dan tidak dijumpai informasi yang menjelaskan bahwa mereka melakukan shalat Dhuhur lagi setelah shalat Jumat. ${ }^{30}$ Petunjuk tersebut diperkuat oleh fatwa ulama Islam kontemporer, di antaranya:

1. Syaikh Athiyyah Shaqar, ketua Dewan Fatwa pada Lembaga Riset Islam alAzhar Cairo, menyatakan Sebagaimana diketahui bahwa shalat Jumat adalah pengganti shalat Dzhuhur, oleh sebab itu, jika shalat Jumat telah dilaksanakan sesuai petunjuk yang sahih, maka hal itu telah menggugurkan shalat Dzhuhur. namun bila tidak dilaksanakan atau dilaksanakan tapi tidak sesuai petunjuk yang sahih, maka wajib melaksanakan shalat Dzhuhur. Sesungguhnya shalat Jumat hukumnya tidak wajib bagi wanita, berdasarkan hadis riwayat Abu Daud dan al-Hakim (shalat Jumat adalah kewajiban pasti bagi setiap muslim secara berjamaah kecuali bagi empat golongan, hamba sahaya, wanita, anak kecil, dan orang sakit) serta hadis Ummu Athiyah yang dikeluarkan oleh Ibnu Khuzaimah ia berkata "Kami telah dilarang untuk mengiringi jenazah dan tidak ada kewajiban shalat Jumat bagi kami”. Meski demikian, andai kaum wanita tetap datang ke masjid melaksanakan shalat Jumat maka hal itu sah dan telah menggugurkan kewajiban melaksanakan shalat Dzhuhur. ${ }^{31}$

2. M. Quraish Shihab, Ulama dan Mufassir Kontemporer Indonesia mengatakan: "Dalam pandangan berbagai mazhab, keempat kelompok manusia di atas (Hamba Sahaya, Perempuan, Anak-anak, dan Orang Sakit) seandainya melaksanakan shalat Jumat, maka shalat mereka tetap sah dan tidak perlu lagi mengerjakan shalat Dzhuhur. Bahkan, Imam syafii menganjurkan agar wanita lanjut usia turut berjamaah shalat Jumat. Kini pun banyak ulama kontemporer menganjurkan agar wanita secara umum ikut berjamaah shalat Jumat". ${ }^{32}$

3. Muhammad bin Shalih al-'Utsaimin, Ulama besar Saudi Arabia, ketika ditanya tentang berapa kali wanita melakukan shalat di hari Jumat? Beliau menjawab "Jika seorang wanita telah ikut shalat Jumat bersama dengan imam (di masjid), maka hendaklah ia menjalankan shalat seperti shalat yang

\footnotetext{
${ }^{30}$ Ahmad al-Syurbashi, Yas'alunaka fi al-Din wa al-Hayah, h. 66.

${ }^{31}$ Athiyyah Shaqar, Ahsanul Kalam fi al-Fatawa wal Ahkam, Juz 1, h. 427.

${ }^{32}$ M. Quraish Shihab, M. Quraish Shihab Menjawab 1001 Soal Keislaman Yang Patut Anda Ketahui, Cet. XII; Jakarta: Lentera Hati, 2012, h. 43.
} 
dijalankan oleh Imam tersebut, adapun bila ia hanya shalat di rumahnya pada hari Jumat maka cukup ia shalat zhuhur saja empat rakaat". ${ }^{3}$

Dengan demikian, jelas dan tegaslah bahwa wanita yang datang ke masjid pada hari Jumat boleh melaksanakan shalat Jumat bersama kaum laki-laki. Perbuatan itu dinilai sah dan sudah menutupi kewajibannya untuk menjalankan shalat Dhuhur.

\section{G. Deskripsi Singkat Desa Bulotalangi Timur}

Desa Bulotalangi Timur terletak di bagian Timur Kecamatan Bulango Timur, tepatnya sebelum desa Tamboo dan sesudah desa Bulotalangi (induk). Tahun 2007 desa ini resmi berdiri dan memiliki luas wilayah mencapai 230 hektar dengan panjang kurang lebih 2,3 km. Desa Bulotalangi Timur memiliki empat dusun, yaitu: 1) DUSUN BUTU; 2) DUSUN TUTUWOTO; 3) DUSUN PADENGO; 4) DUSUN TAPALU. Total jumlah penduduknya berjumlah 907 jiwa. Masyarakatnya umumnya berprofesi sebagai petani/buruh tani. Sebagian kecil berprofesi sebagai montir, karyawan perusahaan swasta dan pemerintah (Honorer), serta PNS dan anggota POLRI. Beberapa fasilitas umum yang dapat dijumpai di desa ini, antara lain: fasilitas kesehatan, fasilitas pendidikan, dan fasilitas ibadah. ${ }^{34}$ Rinciannya dapat digambarkan masing-masing sebagai berikut:

Tabel 1.

Fasilitas Umum Yang Ada di Desa Bulotalangi Timur

\begin{tabular}{|l|l|}
\hline \multicolumn{1}{|c|}{ JENIS FASILITAS UMUM } & \multicolumn{1}{c|}{ JUMLAH/UNIT } \\
\hline POSKESDES & 1 unit \\
\hline TK & 1 unit \\
\hline RA & 1 unit \\
\hline MI & 1 unit \\
\hline MTs & 1 unit \\
\hline MASJID & 3 unit \\
\hline
\end{tabular}

Sumber Data:

Buku Profil Desa Bulotalangi Timur, Oktober 2014.

\footnotetext{
${ }^{33}$ Muhammad bin Shalih al-Utsaimin, Fatawa Arkan al-Islam, Cet II; Riyad, Dar al-Tsaraaya li al-Nasyr, 1426 H, h. 389.

${ }^{34}$ Data sesuai buku "Profil Desa" yang terdapat di kantor desa.
} 
Menurut Triswinda Utina, Sekretaris Desa Bulotalangi Timur:

"Memang 100\% penduduk di desa ini beragama Islam. Itulah sebabnya tidak heran kalau di desa ini berdiri sampai tiga buah masjid sekaligus. Ketiganya merupakan sarana ibadah vital dan menjadi fokus kegiatan keagamaan masyarakat setiap hari dengan shalat lima waktu, setiap pekan dengan ibadah shalat Jumat, serta setiap tahun dengan dua shalat 'Ied". 35

Ketiga masjid yang dimaksud adalah: 1) Masjid al-Hidayah. Letaknya berada di sebelah Timur kantor desa. Dibangun pada tahun 1971, dan pada awalnya hanya digunakan sebagai Musholla. Semenjak didirikan masjid ini telah dipimpin oleh dua orang Imam, yaitu: Abidin Mantu (sejak tahun 1980-1994, dan 2013 sampai sekarang), kemudian Sulaiman Hasan (sejak tahun 1994-2013). 2) Masjid Darul Lisamdih. Masjid yang dibangun oleh seorang dermawan bernama Lisa Dama ini dibangun pada tahun 2009 dan letaknya berada di Dusun III Padengo, sebelah Barat kantor desa Bulotalangi Timur. Imamnya bernama Abu Bakar Abdulah (60 tahun) dan belum pernah diganti semenjak menjabat sebagai Imam sampai sekarang. 3) Masjid Nurul Hasanah. Terletak di pinggir jalan poros kecamatan Bulango Timur dan didirikan pada tahun 2007. Imamnya bernama Alex Lintangadi yang juga sekaligus menjabat sebagai ketua takmir masjid.

Melihat data di atas, dapat ditarik kesan bahwa kondisi desa Bulotalangi Timur secara umum masih memprihatinkan. Tercatat ada sekitar 300 jiwa yang tidak tamat SD. Sementara yang tamat SMP dan SMA masing-masing hanya sekitar 100 orang. Dan yang tamat S1 hanya 3 orang. ${ }^{36}$ Statistik ini mencerminkan bahwa desa Bulotalangi Timur termasuk daerah/desa dengan tingkat kesadaran pendidikan yang sangat rendah.

\section{H. Model Shalat Para Wanita di Desa Bulotalangi Timur Pada Hari Jumat}

Setelah melakukan penelusuran di tiga masjid yang ada di desa Bulotalangi Timur, ditemukan data bahwa masjid yang muslimahnya hanya datang menjalankan

\footnotetext{
${ }^{35}$ Triswinda Utina, Sekretaris Desa Bulotalangi Timur, Wawancara (3 Oktober 2014) di Kantor Desa Bulotalangi Timur.

${ }^{36}$ Triswinda Utina, Sekretaris Desa Bulotalangi Timur, Wawancara (2 November 2014) di Kantor Desa Bulotalanngi Timur.
} 
shalat Dhuhur pada hari Jumat hanyalah jemaah yang ada di masjid al-Hidayah Dusun IV Tapalu. Meski demikian, menurut keterangan yang diperoleh dari Safri Akase, Sekretaris Takmir masjid Nurul Hasanah Dusun I Butu, bahwa sebenarnya di masjid Nurul Hasanah dulu juga pernah berlangsung model shalat Jumat seperti itu, tapi sekarang sudah gabung sama-sama. ${ }^{37}$

Kondisi yang hampir sama juga terjadi pada masjid al-Hidayah. Di mana awalnya, pada tahun 1984 ketika pertama kali masjid itu dipakai untuk shalat Jumat, muslimahya pernah melangsungkan shalat Jumat secara serentak mengikut kepada kaum laki-laki selama 10 tahun. Namun, sejak masuk tahun 1994 wanita sudah mulai memisahkan diri dan melakukan shalat jamaah Dhuhur sendiri. Hal ini sebagaimana disampaikan oleh Bapak Abidin Mantu dan dibenarkan oleh Bapak Sulaiman Hasan. ${ }^{38}$

Setelah dilakukan pengamatan, model pelaksanaan shalat Jumat muslimah di masjid al-Hidayah dapat digambarkan sebagai berikut:

1. Saat azan shalat Jumat dikumandangkan lewat speaker masjid, kaum wanita berduyun-duyun datang ke masjid satu persatu hingga menjelang khatib membaca khutbah kedua. Setelah kaum muslimah tersebut sampai di masjid, umumnya mereka langsung duduk dan tidak melakukan shalat sunnah tahiyyatul masjid atau shalat sunnah mutlak. Mereka tetap tenang dan terus mendengarkan khutbah dengan seksama hingga khatib selesai membacakan khutbah kedua.

2. Pada saat iqamah untuk shalat jumat dikumandangkan, kaum wanita tetap duduk tenang sementara kaum lelakinya berdiri dan mengatur saf-saf mereka bersiap untuk shalat jumat. Kondisi itu terus berlanjut pada saat shalat Jumat berlangsung sampai imam mengucapkan salam pertanda telah selesainya pelaksanaan shalat Jumat.

3. Tahap selanjutnya, salah seorang dari jamaah laki-laki bernama Sulaiman Hasan (ketua takmir masjid) menuju ke shaf wanita dan berdiri satu shaf di depan shaf para wanita persis di bagian tengah. Para wanita pun mengatur shaf-nya sekaligus bersiap mengikuti aba-aba dan gerakan dari ka' usu

\footnotetext{
${ }^{37}$ Safri Akase, Sekretaris Takmir Masjid Nurul Hasanah, Wawancara (31 Oktober 2014) di masjid Nurul Hasanah desa Bulotalangi Timur.

${ }^{38}$ Abidin Mantu, Imam Masjid al-Hidayah, Wawancara (10 Oktober 2014) di masjid al-Hidayah Bulotalangi Timur.
} 
(nama panggilan pak Sulaiman). Setelah itu, imam mengangkat Takbiratul Ihram dengan suara jahar lalu diikuti oleh jamaah wanita. Demikianlah, shalat tersebut berlangsung sebanyak empat rakaat dan ditutup dengan salam.

Dari gambaran itu dapat difahami bahwa shalat jamaah yang dilakukan oleh kaum wanita di masjid al-Hidayah itu adalah shalat Dhuhur dan bukan shalat Jumat atau shalat lainnya. Hal itu ditandai dengan rakaatnya yang berjumlah empat rakaat, bacaan shalatnya dilakukan dengan sir (kecuali aba-aba dari imam dilakukan dengan jahar), tahiyat dua kali dan hanya sekali salam.

Setelah dikonfirmasi kepada jamaah wanita dan imamnya, mereka memberi jawaban yang sama bahwa shalat yang mereka lakukan adalah shalat Dhuhur. ${ }^{39}$ Dilihat dari jumlah jamaah kaum wanita yang hadir shalat Jumat selama pengamatan dan penelitian berlangsung dari bulan April sampai dengan bulan November 2014, rata-rata berjumlah 12 sampai 20 orang. Dengan rentang usia berfariasi antara 16 sampai 60 tahun. Sebagaimana dipaparkan oleh ibu Fatmah Bague (54 tahun) istri dari Imam Masjid al-Hidayah. ${ }^{40}$

\section{Asal Mula Munculnya Faham Larangan Shalat Jumat Bagi Wanita di Desa Bulotalangi Timur}

Asal mula lahirnya faham shalat Jumat muslimah di masjid al-Hidayah desa Bulotalangi Timur ini tidak dapat dipisahkan dari sejarah berdirinya masjid alHidayah, serta bagaimana kondisi riil masyarakat sekitar saat itu. Berdasarkan informasi dari Bapak Abidin Mantu, Imam Masjid dan Tokoh Pendiri masjid alHidayah. $^{41}$

Sementara itu, pengakuan Yusuf Akululu, Imam Wilayah di desa Bulotalangi Timur yang juga tinggal di sekitar masjid al-Hidayah mengatakan "Pada tahun 1984, kami di masjid al-Hidayah pernah shalat Jumat bersama dengan wanita. Mereka mengikut dan menjadi makmum bersama pria yang turut hadir shalat Jumat. Hal itu

\footnotetext{
${ }^{39}$ FGD dengan jamaah (10 Oktober 2014) di masjid al-Hidayah desa Bulotalangi Timur.

${ }^{40}$ Fatmah Bague, Wawancara (31 November 2014) di kediamannya Dusun Tapalu desa Bulotalangi Timur.

${ }^{41}$ Abidin Mantu, Imam Masjid Jami' al-Hidayah, Wawancara (10 Oktober 2014) di masjid al-Hidayah desa Bulotalangi Timur.
} 
berlangsung kurang lebih 10 tahun. Namun, setelah terjadi pergantian Imam Masjid ke tangan Sulaiman Hasan pada tahun 1994, mulailah kaum Muslimah desa Bulotalangi Timur melakukan shalat Dhuhur sendiri secara terpisah meski mereka tetap datang ke masjid untuk menghadiri panggilan ibadah shalat Jumat" ${ }^{42}$

Data lainnya yang juga ditemukan di lapangan menunjukkan bahwa awal mula lahirnya cara shalat Jumat muslimah desa Bulotalangi Timur ini diperoleh dari seorang ustadz yang berprofesi sebagai penceramah/da'i. Orang itu dikenal dengan sebutan ka' Nano dan masih hidup hingga sekarang. Ia tinggal di desa Bulotalangi Induk dan masih sering diundang oleh takmir masjid ceramah pada hari-hari besar Islam atau ketika ada kematian. Data ini diperoleh dari Ibu Fatmah Bague, ia mengatakan "Kami mengetahui faham ini dari ka' Nano itu. Dialah yang mengajari kami tentang cara shalat Jumat seperti itu untuk kaum wanita. Kalau saya tidak salah ingat, ka' Nano itu yang lebih dulu mengajarkan faham shalat Jumat itu kepada kami sebelum Karim Daud. Dan kami sudah percaya kepada apa yang beliau sampaikan tersebut" ${ }^{43}$

Dengan demikian, dapat dikemukakan bahwa aktor intelektual dibalik dari hadirnya cara shalat Jumat muslimah di desa Bulotalangi Timur adalah dari dua tokoh agama. Yang pertama Bapak Karim Daud sebagai pembimbing pengajian Al-Qur'an, dan kedua adalah Bapak Sukarno Tahir (Ka' Nano) sebagai penceramah/da'i sekaligus pemimpin halaqah zikir di Bulotalangi Induk.

Akurasi data ini dikonfirmasi ke beberapa pihak, antara lain Bapak Jon K. Adam, Kepala Desa Bulotalangi Timur. Beliau mengatakan:

"Saya tidak kenal dengan saudara Karim Daud. Tapi kalau dia pernah mengajar masyarakat sini mengaji di masjid al-Hidayah, mungkin saya juga pernah diajar ngaji karena memang saya juga dulu belajar ngaji sama ustadz di masjid situ tapi saya tidak tahu siapa namanya karena saat itu kami masih kecil. Sementara kalau ka' Nano saya kenal baik dengan beliau karena dia itu da'i di daerah Bulotalangi sini. Namanya Sukarno Tahir dan beliau tinggal di desa Bulotalangi Induk. Pekerjaan sehari-harinya adalah sebagai penceramah. Selain itu, ia juga punya majelis zikir di rumahnya setiap malam Rabu. Ia punya banyak murid yang

\footnotetext{
${ }^{42}$ Yusuf Akululu, Imam Wilayah, Wawancara (10 Oktober 2014) di masjid al-Hidayah desa Bulotalangi Timur.

${ }^{43}$ Fatma Bague, Wawancara (31 Oktober 2014) di kediamannya di Dusun IV.
} 
berguru kepadanya. Termasuk beberapa tokoh masyarakat di desa Bulotalangi Timur sini adalah murid-muridnya. Seperti Bapak Abidin Mantu, Bapak Sulaiman, dan Bapak Yusuf Akululu. Saya sempat diajak oleh beliau untuk ikut di majelis zikirnya tapi hanya dua kali kemudian saya tidak ikut lagi, karena persoalan tata cara zikirnya yang menurut saya sebagai orang yang masih awam dari segi pengetahuan agama, kurang etis dan tidak logis. Seperti: saat berzikir lampu dimatikan semua; lafalnya banyak yang tidak jelas, utamanya lafad LAILAHA ILLALLAAH, semakin lama lafadnya habis, sehingga tinggal inlah...inlah... kemudian ah...ah... mh.... Hanya itu yang saya tahu".

Informasi tersebut dibenarkan oleh Bapak Abidin Mantu. menurutnya: "Bapak Sukarno Tahir itu seorang da'i yang sering diundang ke mana-mana. Bahkan, sampai ke luar negeri (Vietnam). Majelis zikirnya selalu dipenuhi orang dari berbagai wilayah. Ada dari Pohuwato, Boalemo, Kabupaten Gorontalo, dari Kotamobagu, dan Manado. Saya sendiri dan beberapa warga di Bulotalangi Timur sebagai jamaah tetapnya. Bapak Sukarno Tahir ini adalah murid dari Adam Zakaria (almarhum) dan Tuan Samadi. Teman seperguruannya adalah Karim Daud. Lainnya ada di Tapa 4 orang, dan di Kabila 2 orang, namanya saya tidak tahu. Setelah berzikir, biasanya diisi dengan ceramah atau kajian tentang hukum dan isi kandungan Al-Qur'an. Pembicara tetapnya adalah ka' Nano sendiri dan Opa dari Buliide Kota Barat" ${ }^{44}$

Faham tentang cara shalat Jumat bagi muslimah seperti itu juga dijumpai di beberapa desa tetangga. Misalnya, desa Bulango Utara, desa Longalo, desa Bunuo, dan desa Tupa. ${ }^{45}$ Oleh sebab itu, dapat diasumsikan bahwa faham halat Jumat ini sudah menyebar di daerah Bulotalangi dan sekitarnya. Diduga kuat faham itu dibawa dan disebarkan secara aktif dan massif oleh Ka' Nano ke berbagai tempat di berbagai kesempatan saat ia berdakwah, khususnya di majelis zikirnya yang muridnya rata-rata adalah Imam dan pengurus masjid.

\footnotetext{
${ }^{44}$ Abidin Mantu, Tokoh Masyarakat, Wawancara (2 November 2014) via sambungan telepon.

${ }^{45}$ Bian Harun, Ibu Rumah Tangga, Wawancara (16 Oktober 2014) di kediaman beliau Dusun IV.
} 


\section{J. Dalil Yang Melandasi Faham Larangan Shalat Jumat Bagi Wanita di Desa Bulotalangi Timur}

Selanjutnya untuk mendalami landasan berfikir masyarakat muslimah Dusun IV Tapalu desa Bulotalangi Timur terkait faham mengenai cara shalat Jumat mereka, maka dilakukan wawancara terbuka di masjid (FGD) dan mempersilahkan kepada para informan (jamaah wanita) siapa saja untuk menjawab pertanyaan dan memberi penjelasan tentang landasan berpikir mereka menjalankan cara shalat Jumat seperti itu.

Adapun pertanyaan yang diajukan adalah apa alasan Ibu-ibu sekalian sehingga tidak mau ikut shalat Jumat bersama kaum lelaki di hari Jumat? Padahal ibu-ibu sekalian sudah hadir di masjid sebelum shalat Jumat dilangsungkan. Bahkan cenderung hadir lebih awal dan sempat mendengar khutbah Jumat?

Dari pertanyaan tersebut, ditemukan jawaban berfariasi dari informan. Yang dapat diuraikan sebagai berikut:

1. Ibu Ewis Mantu (29 tahun) ${ }^{46}$ :

"Bahwa di dalam Al-Qur'an surah al-Jumuah ayat 9 di situ disebutkan bahwa apabila kalian para laki-laki diseru untuk menunaikan shalat Jumat, maka segeralah datang untuk mengingat Allah dan tinggalkan jual beli. Ini menjadi dalil yang tegas dari Allah bahwa shalat Jumat hanya khusus bagi laki-laki”

2. Meiris Arfan (16 tahun) ${ }^{47}$ :

"Shalat Jumat bagi wanita tidak wajib. Bahkan, tidak boleh sama sekali. Sampai-sampai dengar khutbah pun tidak diperbolehkan karena dua khutbah itu termasuk dalam rangkaian shalat Jumat”.

3. Ibu Hasni Akululu (38 tahun) ${ }^{48}$ :

\footnotetext{
${ }^{46}$ Ewis Mantu, Guru Honorer di MI al-Hidayah, Wawancara (10 Oktober 2014) di masjid al-Hidayah desa Bulotalangi Timur.

${ }^{47}$ Meiris Arfan, Mahasiswi UNG Jurusan Fisika Semester I, Wawancara, (10 Oktober 2014) di masjid alHidayah desa Bulotalangi Timur.

${ }^{48}$ Hasni Akululu, Ibu Rumah Tangga, Wawancara (10 Oktober 2014) di masjid al-Hidayah desa Bulotalangi Timur.
} 
"Kami sudah dapati cara dan kebiasaan itu dari kecil. Sesuai yang saya ketahui wanita tidak boleh shalat Jumat. Hanya bisa shalat Dhuhur. Sebab hanya laki-laki yang diwajibkan oleh agama".

4. Ibu Fatmah Bague (54 tahun) ${ }^{49}$ :

"Perempuan sebenarnya boleh shalat Jumat tapi wajibnya perempuan itu hanya shalat Dhuhur. Kalau wanita datang shalat Jumat, ia tidak boleh ikut shalat Jumat bersama laki-laki atau harus berpisah. Itu saya dapatkan dari ustad bernama ka' Nano. Dia penceramah di sini dan saya memegang teguh omongannya".

Pertanyaan selanjutnya yang diajukan adalah mengapa ibu-ibu harus datang ke masjid pada hari Jumat ini dan mengapa tidak shalat di rumah saja?

Dari pertanyaan tersebut diperoleh jawaban sebagai berikut:

1. Meiris Arfan:

"Karena pahala shalat berjamaah itu lebih tinggi atau lebih besar dari shalat sendirian. Apalagi kalau dilakukan di masjid, maka lebih afdhal lagi dan paling banyak pahalanya".

2. Hasni Akululu:

"Kami suka dapat pahala yang banyak. Kalau shalat di masjid shalatnya bisa berjamaah dan ada laki-laki yang bisa mengimami kami. Kalau di rumah hanya shalat sendiri"

Pertanyaan selanjutnya, Mengapa kaum wanita yang datang ke masjid tidak shalat berjamaah sendiri saja dengan menunjuk salah seorang di antara kaum wanita yang hadir untuk jadi imam? Jawaban informan Hasni Akululu hanya satu, yaitu:

"Karena kami takut jadi imam. Kami kan tidak tahu tata cara jadi Imam shalat. Apalagi kami belum menguasai bacaan dan doa dalam shalat. Sementara yang kami tahu, imam itu bertanggungjawab sama

\footnotetext{
${ }^{49}$ Fatma Bague, Ibu Rumah Tangga, Wawancara (31 Oktober 2014) di kediamannya di Dusun IV.
} 
makmumnya. Baik bacaan maupun gerak-geriknya. Makanya semua ibu-ibu di sini tidak ada yang berani jadi imam. ${ }^{50}$

Dari berbagai jawaban di atas, dapat disimpulkan bahwa tidak ada alasan atau dalil mendasar dari ibu-ibu muslimah desa Bulotalangi Timur yang bisa dikategorikan sebagai alasan syar'i yang mendasari pemikiran dan faham mereka menjalankan shalat Jumat seperti itu. Adapun dalil yang dikemukakan oleh Ibu Ewis Mantu yang merujuk kepada QS. al-Jumu'ah ayat 9 adalah dalil yang keliru. Sebab, redaksi terjemah dari ayat tersebut tidak ada penyebutan kata "laki-laki" sebagaimana terjemah resmi Kementerian Agama.

\section{K. Faktor Yang Mempengaruhi Langgengnya Faham Larangan Shalat Jumat Bagi Wanita}

Setelah mendapatkan banyak informasi dan data dari para informan serta pelaku shalat Jumat di desa Bulotalangi Timur, dapat dirumuskan faktor atau penyebab kukuhnya muslimah di masjid al-Hidayah mempertahankan faham tersebut, antara lain:

1. Rendahnya tingkat pendidikan yang dimiliki oleh penduduk desa Bulotalangi Timur sejak dahulu hingga sekarang. Sehingga hal ini turut berpengaruh pada cara pandang dan cara berfikir masyarakatnya khususnya di bidang agama. Selain itu, minimnya pengetahuan agama muslimah desa Bulotalangi Timur, khususnya jamaah masjid al-Hidayah. Itu dapat dilihat dari tidak adanya yang bisa menjadi imam karena rata-rata tidak tahu jadi imam dan tidak tahu bacaan shalat. Di tambah lagi pengetahuan agama mereka umumnya didapat lewat apa yang mereka warisi, lihat, dan dengar dari orang yang ada di lingkungannya.

2. Rendahnya perhatian tokoh masyarakat, pemerintah setempat, serta ahli agama untuk merespon fenomena ini. Sebab sampai saat ini menurut pengakuan dari Kepala Desa dan warga sekitar belum pernah ada yang mempersoalkan fenomena cara shalat Jumat tersebut dan belum pernah dibincangkan pada tingkat desa atau

\footnotetext{
${ }^{50}$ Asni Akululu, Ibu rumah Tangga, Wawancara (10 Oktober 2014) di masjid Jami' al-Hidayah desa Bulotalangi Timur.
} 
takmir masjid. ${ }^{51}$ Bahkan cenderung dianggap normal dan biasa saja oleh pihak pemerintah maupun masyarakat sekitar.

3. Adanya faham yang dipegang secara fanatik oleh sebagian besar masyarakat muslimah bahwa wanita tidak boleh shalat Jumat. Meski demikian, ada harapan muslimah desa Bulotalangi Timur bisa meninggalkan kebiasaan ini. Yaitu bila ada tokoh yang bisa dihadirkan untuk memberi penjelasan tentang tata cara shalat Jumat yang sebenarnya menurut agama. Sebagaimana respon atas pertanyaan bagaimana seandainya di kemudian hari ada orang/ustad/kiyai/tokoh masyarakat/unsur lembaga pemerintah yang datang memberi petunjuk/penjelasan tentang hukum shalat Jumat yang sebenarnya bagi wanita menurut hukum Islam, apakah ibu-ibu mau terima dan mau meninggalkan cara/faham yang ibu pegang selama ini? 4 orang menyatakan tidak mau tinggalkan, 6 orang lainnya netral, kemudian yang setuju dan siap meninggalkan sebanyak 2 orang. Data ini menunjukkan bahwa jamaah masjid al-Hidayah menunggu pihak terkait untuk datang meluruskan faham ini.

4. Tertutupnya muslimah masjid al-Hidayah dari akses informasi. Baik itu Radio maupun televisi. Artinya, umumnya mereka tidak pernah mendengar ceramah dan taushiyah di televisi atau radio. Khususnya acara Hikmah Pagi RRI atau Dakwah Islam di TVRI stasiun Gorontalo. Mereka lebih banyak mendengar taushiyah tatkala ada kematian atau hari perayaan hari besar Islam di masjid. Itupun narasumber yang diundang sering kali da'i yang sama, yaitu Sukarno Tahir.

5. Terjadinya interaksi sosial yang intensif antar warga Desa Bulotalangi Timur satu sama lain khususnya yang ada di dusun IV Tapalu, serta kontak sosial dan komunikasi yang intensif antara beberapa tokoh masyarakat dusun Tapalu (takmir masjid) dengan bapak Karim Daud dan Sukarno Tahir. Baik secara fisik maupun komunikatif. Secara teori, hal ini dapat menjadi salah satu faktor pemicu

\footnotetext{
${ }^{51}$ Jon K. Adam, Kepala Desa Bulotalangi Timur, Wawancara (31 Oktober 2014) di Kantor Desa Bulotalangi Timur.
} 
terjadinya perkembangan hukum Islam. ${ }^{52}$ Bahkan, diduga dapat melahirkan sikap fanatisme faham keagamaan di masyarakat.

\section{Respon Masyarakat Atas Faham Larangan Shalat Jumat Bagi Wanita di Desa \\ Bulotalangi Timur}

Terkait persoalan ini, penelusuran data dilakukan dengan meminta respon dari beberapa pihak yang terkait langsung dan tidak langsung dengan kondisi masyarakat desa Bulotalangi Timur. Mulai dari unsur pemerintah, tokoh masyarakat, serta penyuluh agama di Kecamatan Bulango Timur.

Sebagai tokoh masyarakat, Bapak Sapri Akaseh menilai "Kami tidak setuju dengan faham shalat Jumat seperti itu bagi wanita. Menurut saya cara itu tidak masuk akal dan tidak benar. Alasan saya adalah: (1) Imam yang menshalati mereka berarti melaksanakan shalat wajib dua kali dalam waktu yang sama. Sekali sebagai makmum shalat Jumat dan sekali sebagai imam shalat Zhuhur. Sementara agama hanya memerintahkan kepada laki-laki untuk shalat Jumat atau shalat Zhuhur bagi yang udzur. (2) Wanita kalau datang ke masjid berarti tetap mendengar khutbah, padahal khutbah itu adalah bagian tak terpisahkan dari shalat Jumat. (3) Shalat Dzhuhur mereka di masjid secara berjamaah padahal mereka hadir sebelum shalat Jumat didirikan. Meski demikian, kami di masjid Nurul Hasanah ketika ada muslimah yang menjalankan seperti itu kami biarkan demi keutuhan jamaah. Tapi begitu imamnya sudah tidak ada lagi maka kami coba dialog dengan mereka dengan membuat rapat bersama takmirul dan akhirnya ibu-ibu mau bergabung. Ditambah lagi setelah kami mendengar dari hikmah pagi RRI. Jadi menurut saya berdasar pengalaman kami di Nurul Hasanah.ada dua hal yang bisa mengubah faham tersebut, Pertama: memberi akses informasi agama lewat Radio atau Televisi kepada masyarakat. Kedua, dialog, keterbukaan, dan kepedulian dari takmirul masjid". 53

\footnotetext{
${ }^{52}$ Abdul Wasik "Korelasi Interaksi Sosial Dalam Perkembangan Hukum Islam di Indonesia" Hukum Islam, Vol: 14, No.1, Juni 2016. Jurusan Syariah dan Ekonomi Islam, STAIN Pekalongan, h. 34.

${ }^{53}$ Sapri Akaseh, Tokoh Masyarakat, Wawancara (31 Oktober 2014) di masjid Nurul Hasanah desa Bulotalangi Timur.
} 
Menurut Kepala Desa Bulotalangi Timur, Bapak Jon K. Adam "Saya belum bisa tentukan sikap antara setuju dengan tidak dari faham itu karena saya juga terbatas dari sisi pengetahuan agama. Selama ini saya cenderung lebih banyak mendorong umat muslim di sini agar shalat jamaahnya dijaga dan kalau bisa semakin bertambah. Terus terang saya belum pernah mempersoalkan itu dengan takmir. Saya hanya pernah tanyakan kepada Bapak Sulaiman Hasan yang sering mengimami mereka mengapa bukan ibu-ibu saja yang jadi imam untuk shalat Dzhuhur mereka. Jawaban pak Sulaiman bahwa "seharusnya memang demikian, tapi karena tidak ada yang mau atau bersedia jadi imam, maka dari pada mereka pulang terpaksa saya imami”. Maka dari itu, saya berasumsi cara itu terpaksa mereka lakukan karena kebanyakan mereka (kaum wanita) tidak tahu jadi imam dan tidak menguasai bacaan shalat". 54

Ibu Fatmah Ngadi, Penyuluh Agama Honorer KUA Bulango Timur mengatakan "Saya tidak setuju dengan cara shalat seperti itu, walaupun sebelumnya saya bersama warga muslimah di sini pernah melakukan, namun setelah saya dengar dari Hikmah Pagi RRI setiap selesai shalat Subuh, bahwa wanita boleh shalat Jumat bersama lakilaki, maka mulai saat itu saya ikut shalat Jumat dengan laki-laki. Saya bersyukur sekali dengan acara Hikmah Pagi karena disitu saya banyak tahu persoalan ibadah menurut ketentuan agama". 55

Dari beberapa keterangan dan sikap tersebut di atas terlihat bahwa masyarakat sekitar desa Bulotalangi Timur belum ada yang mempersoalkan faham shalat Jumat muslimah masjid al-Hidayah tersebut. Hal itu dipicu karena pengetahuan agama mereka juga masih minim dan mereka menjaga agar persoalan itu tidak menjadi ladang konflik yang bisa meretakkan kebersamaan dan kerukunan mereka yang sudah lama terbina.

\section{Kesimpulan}

\footnotetext{
${ }^{54}$ Jon K. Adam, Kepala Desa Bulotalangi Timur, Wawancara (31 Oktober 2014) di Kantor Desa Bulotalangi Timur.

${ }^{55}$ Fatmah Ngadi, Penyuluh Agama Honorer, Wawancara (31 Oktober 2014) di rumah Mastin Supu desa Bulotalangi Timur.
} 
Berdasarkan data yang telah diuraikan di atas, dapat ditarik suatu kesimpulan bahwa dari tiga masjid yang ada di desa Bulotalangi Timur, hanya masjid al-Hidayah yang muslimahnya menjalankan faham bahwa wanita tidak boleh shalat Jumat. Faham ini muncul sejak tahun 1994 yang diajarkan oleh seorang guru ngaji bernama Karim Daud dan Sukarno Tahir. Sebelum adanya faham yang disebarkan dari kedua guru tersebut, muslimah desa Bulotalangi Timur melaksanakan shalat Jumat bersama antara laki-laki dan perempuan. Setelah ditelusuri, tidak dijumpai adanya dalil nas khusus yang melandasi faham tersebut. Langgengnya faham tersebut dipicu oleh sedikitnya 5 faktor: 1) Rendahnya tingkat pendidikan dan pengetahuan agama warga desa tersebut; 2) Kurangnya perhatian dari lembaga pemerintah dan tokoh masyarakat setempat; 3) Adanya fanatisme buta atas doktrin sang guru/ustad; 4) Kurang tersentuhnya mereka oleh dakwah dan pencerahan dari ulama di Gorontalo, baik dari MUI, IAIN, maupun Kementerian Agama; 5. Masih intensifnya interaksi dan komunikasi antara warga Dusun Tapalu dan warga Desa lain dengan Sukarno Tahir. Sebagai implikasinya, perlu dilakukan pendampingan secara intensif di masjid al-Hidayah dalam bentuk majelis taklim atau pengajian rutin, baik oleh pihak KUA, IAIN atau MUI. Perlunya dilakukan penelitian lanjutan terkait sepak terjang Sukarno Tahir dan kelompok zikirnya. Serta perlunya memaksimalkan dakwah melalui radio dan televisi yang ada di Gorontalo agar dapat diserap secara lebih luas oleh masyarakat perdesaan.

\section{DAFTAR PUSTAKA}

al-Bagdādi, Al-Alūsì. Rūh al-Ma'ānī fi Tafsìr al-Qur'āni al-Azīm wa al-Sab'i alMatsānīi, Juz 28, Beirut: Dār Ihyā' al-Turāts al-‘Arabī, t.th.

Departemen Agama RI, Syamil Al-Qur'an; Al-Qur'an dan Terjemahnya (Edisi Tajwid), Bandung: Syamil Cipta Media, t.t.

Himpunan Fatwa Majelis Ulama Indonesia Sejak 1975, Jakarta: Erlangga, 2011.

al-Hajjaj, Muslim bin Abul Hasan al-Qusyairy al-Naisabury. Sahih Muslim, Juz 1, Bab: Fadhlu Shalat al-Jumu'ah, Beirut: Dar Ihya al-Turats al-Araby, t.th. 
Ismail, Muhammad Bakr. al-Fiqh al-Wadhih min al-Kitab wa al-Sunnah 'ala almadzahib al-arba'ah, Jilid 1, Cet. II; Kairo: Dar al-Manar, 1997.

Kamil, Syaikh bin Uwaidah, al-Jami' fi Fiqh al-Nisa', diterjemahkan oleh M. Abdul Ghoffar E.M dengan judul “Fiqh Wanita (Edisi Lengkap), Cet. X; Jakarta: Pustaka al-Kautsar, 2002.

Mikam, Komarudin Ibnu. Rahasia dan Keutamaan Hari Jumat, Cet. I; Jakarta: QultumMedia, 2007.

al-Naisabury, Muhammad bin Ishak bin Khuzaimah. Shahih Ibnu Khuzaimah, Juz 3, Cet. II; Beirut: al-Maktab al-Islamy, 1992.

al-Qurthuby, Jami' li Ahkam al-Qur'an, Jilid 9, Juz 18, Cet. I; Beirut: Dar al-Kutub alIlmiyyah, 2000.

Sabiq, al-Sayyid, Fiqh al-Sunnah, Juz: 1, Cet. II; Cairo: Dar al-Fath li al-I'lam al'Araby, 1999.

Shaqar, Athiyyah. Ahsanul Kalam fi al-Fatawa wal Ahkam, Juz 3, Cairo: Dar al-Gad al-Araby, t.th.

al-Shan'any, Muhammad bin Ismail al-Yamany. Subul al-Salām, Juz 2, Mansoura: Makatabat al-Iman, t.t.

Shihab, M. Quraish. M. Quraish Shihab Menjawab 1001 Soal Keislaman Yang Patut Anda Ketahui, Cet. XII; Jakarta: Lentera Hati, 2012.

Sumardi, Dedi "Islam, Pluralisme Hukum dan Refleksi Masyarakat Homogen" AsySyir'ah; Vol. 50, No. 2, Desember 2016, UIN Ar-Raniry Banda Aceh.

Syakur, Ahmad Bisyri. Fiqh Tradisi; Cara Baru Memandang Tradisi Islam di Indonesia, Cet. I; Bandung: Salamadani, 2013.

Syarifuddin, Amir. Ushul Fiqh 1, Cet. III; Jakarta: Kencana, 2008.

al-Syurbashi, Ahmad. Yas'alunaka fi al-Din wa al-Hayah, diterjemahkan oleh Ahmad Subandi denan judul "Yas'alunaka; Tanya Jawab Tentang Agama dan Kehidupan”, Buku V, Cet. VI; Jakarta: Lentera, 2007. 
Umar, Ahmad Mukhtar Abdul Hamid. Mu’jam al-Lugah al-Arabiyyah al-Mu'āṣirah, Juz 1, Cet. I; Cairo: ‘'̄llam al-Kitāb, 2008.

al-Utsaimin, Muhammad bin Shalih. Fatawa Arkan al-Islam, Cet II; Riyad, Dar alTsaraaya li al-Nasyr, $1426 \mathrm{H}$.

Wasik Abdul "Korelasi Interaksi Sosial Dalam Perkembangan Hukum Islam di Indonesia" Hukum Islam, Vol: 14, No.1, Juni 2016. Jurusan Syariah dan Ekonomi Islam, STAIN Pekalongan.

Yani, Ahmad Nasution “Ta'addud al-Jum' at Menurut Empat Mazhab”, Jurnal Mandiri, Vol. I, No.1, Juni 2017, Lembaga Kajian Demokrasi dan Pemberdayaan Masyarakat.

al-Zuhaily, Wahbah. al-Fiqh al-Islämi wa Adillatuh, Juz 2, Cet. IV; Damaskus: Dar alFikr, 2002.

al-Tafsirir al-Munir, Juz 28, Cet. II; Damaskus: Dar al-Fikr al-Mu'ashir, 1418 $\mathrm{H}$. 